\title{
VALUATION TECHNIQUES OF FRESHNESS OF POULTRY EGGS
}

\author{
Pavel Tsarenko ${ }^{1}$, Igor Popov ${ }^{1}$, Ivan Paronyan ${ }^{2}$, Sawa Hohrin ${ }^{1}$ \\ ${ }^{1}$ Saint-Petersburg State Agrarian University, Russia; ${ }^{2}$ All-Russian Research Institute of Genetics and \\ Breeding of Farm Animals, Saint-Petersburg, Russia \\ segwan@rambler.ru
}

\begin{abstract}
Comparative characteristics of different methods for estimation of freshness of eggs are presented: by the air chamber size; reducing the weight of eggs; mobility yolk; protein consistency; the index of albumen and yolk; and other indicators. The advantage of assessment eggs by freshness index, actual density to the initial density (fresh eggs) is described. The initial density is determined by elastic deformation of the shell, which does not change during storage of eggs. A table has been developed to determine the initial density by elastic deformation. The notion "hydro-density" (in $\mathrm{mg} \cdot \mathrm{cm}^{-3}$ ) is introduced; the mass of an egg in distilled water did not change the volume during storage. "Hydro-density" is a simplified expression of density: $1085 \mathrm{~g} \cdot \mathrm{cm}^{-3}$ equals to $85 \mathrm{mg} \cdot \mathrm{cm}^{-3}$. The freshness index varies from 100 to $0 \%$ (the egg floats in water). It is proposed that if eggs have the freshness index $88 \%$ they are considered as dietary eggs, which have $64 \%$ - as table eggs; that corresponds to daily shrinkage of eggs not more than $0.17-0.14 \%$. The valuation technique of eggs by the freshness index is objective, it does not require opening the eggs and can be used for quality control of food and hatching eggs.
\end{abstract}

Keywords: "hydro-density", egg, freshness of eggs.

\section{Introduction}

The egg is the best source of amino acids, which the UN FAO adopted as the standard [1]. However, an egg is a highly unsustainable biological stuff, because of a huge variety of nutrients and biologically active substances enclosed in a small package. These substances are suspension systems that facilitate interaction between them and progress in inevitable reactions. Moreover, through the pores of the eggshell inside the egg aggressive oxygen and various bacteria penetrate. In this regard, the egg quickly loses its freshness, gets old and becomes unfit for food purposes or reproduction (incubation) [2]. The aging process starts immediately after laying eggs [3]. Dissolved carbon dioxide in protein (average $3.5 \mathrm{mg}$ per day) exits through the pores of the shell from the egg in the first days. With loss of $\mathrm{CO}_{2}$ the protein $\mathrm{pH}$ (from 7.6 to 9.2) significantly increases. This leads to rapid destruction of the gel consistency of the protein dense layer [4-6]. An aging egg accompanied by loosening shell of yolk is up to rupture. The old egg lost its protective reserves, exposed various kinds of bacteria and fungi leading to its final damage $[4 ; 5 ; 7]$.

For successful effort to contain aging and to preserve freshness of eggs it is necessary to assess its "age" objectively. There are several methods of estimating the age of eggs, one of them onto the intact egg, the others after its autopsies.

Currently, many researches have been focused on egg quality examination. For example, different non-destructive techniques for automatically detecting cracks, dirt and blood spots have been investigated [9-11]. Although these criteria could be useful as exclusion criteria in an on-line system, they could not demonstrate the internal quality of eggs. Therefore, the researchers' attention focuses on the development of non-invasive and non-destructive instrumental techniques such as infrared and front face fluorescence spectroscopy. The potential of visible-near transmission spectra for the assessment of egg freshness and the properties of egg white quality has been demonstrated by several studies [12-15].

Giunchi et al. [16] investigated the NIR reflectance for qualitative measurement of egg freshness according to the days of storage. Predictive models showed $R^{2}$ values up to $0.722,0.789$ and 0.676 for theair cell height, thick albumen heights and the Haugh unit, respectively.

Kemps et al. [17] investigated the feasibility of visible transmission spectroscopy as a nondestructive assessment of freshness of an individual egg. A partial least squares (PLS1) model was built in order to predict the Haugh unit [17] and $\mathrm{pH}$ of the albumen based on the transmission spectra. The correlation coefficients between the predicted values and the measured values were 0.842 and 0.867 for the Haugh unit and $\mathrm{pH}$ of the albumen, respectively [17].

The aim of this work is to compare the existing methods to determine freshness of eggs in terms of their accuracy and practical application. 


\section{Materials and methods}

The research was on chicken and quail eggs. Each sample of eggs was assessed by 12 different biophysical indicators (maximum of 25) [2]. In the experiments, the eggs were stored in the laboratory or in the refrigerator for 20-30 days (up to 120), evaluating them through a certain period of time (3, 7, or 10 days). In these experiments more than 5 thousand eggs were assessed.

During the research special attention was paid to freshness of eggs, the size of the air chamber, loss of mass, dynamics of the density, mobility of yolk, the index of albumin and yolk.

The data were analyzed using SAS® (version 9.1, 2003) statistical software package and The Unscrambler ${ }^{\circledR}$ (version 9.7, 2007). Multivariate analysis of the samples was performed in The Unscrambler program. The models obtained were validated by using the leave-one-out crossvalidation method. In the leave-one-out method, all data are used to build the model, except the one used to test this model. The slope and the intercept of regression lines were calculated and compared with their ideal values of 0 and 1, respectively using a statistical program called IRENE® (version Beta 1.00, 2003) [8].

\section{Results and discussion}

Under identical storage conditions, the parameters of the air chamber (height and diameter) of large eggs compared with small ones are significantly higher. Therefore, the air chamber of eggs C-2 $(45-55 \mathrm{~g})$ and $\mathrm{CO}(65-75 \mathrm{~g})$ equal freshness cannot be compared. The chamber dimensions also depend on the sphericity blunt pole of the egg: spindly form, thereby more its height, and less its diameter.

It is established that increasing the shape index (rounded eggs) by $8 \%$, the height of the chamber reduced by $1.13 \mathrm{~mm}$, and increasing the egg weight by $6 \mathrm{~g}$ increased it by $0.61 \mathrm{~mm}$.

It should be noted that during storage of eggs the height and diameter of the air chamber grow with increasing the distance from the blunt pole of the egg.

Thus, the simple and affordable method of assessing freshness of eggs by the dimension of the air chamber should be used with caution, taking into account the aforementioned features.

The ideal method to assess freshness of eggs by shrinkage (loss of volume into the egg) is weighin "before" and "after" a certain period of storage $\left(M_{2}-M_{1}\right)$, by the weight loss.

The advantage of this method is accuracy, the ability to group evaluation, simplicity, and speed.

Herewith, the absolute shrinkage in grams, the relative shrinkage in percent to the initial mass $\left(M_{1}\right)$ and the average shrinkage are calculated.

In the experiment, the initial egg weight $\left(M_{1}\right)$ was $62.7 \mathrm{~g}$, and after 30 days of storage it was $59.7 \mathrm{~g}\left(M_{2}\right)$; the egg had shrinkage by $3.0 \mathrm{~g}\left(M_{1}-M_{2}\right)$, or $4.8 \%$, compared to the initial mass; the average shrinkage of the mass was $0.16 \%$. The best indicator of the rate of aging eggs is average shrinkage. Depending on the egg quality and storage conditions it varies in a wide range: from $0.1 \%$ to $0.4-0.6 \%$. Than higher this indicator, the sooner the egg will be "aging". In laboratory storage conditions, the daily shrinkage ranges from 0.15 to $0.25 \%$, depending on the temperature and humidity.

However, the weight method for determining the biological age of eggs has a very significant drawback, the lack of data on the initial egg weight $(M 1)$.

Therefore, to judge about freshness of eggs is more convenient according to their density (P), that is, the mass divided by the volume $(V)$. The advantage of this method is that the volume of eggs during storage remains virtually unchanged, i.e. $V_{1}=V_{2}$.

The ratio of mass to volume of the assessed egg gets its density, $\mathrm{g} \cdot \mathrm{cm}^{-3}$. The lower density leads to the greater air chamber, accordingly higher shrinkage and "older" egg. Using this method is compounded by the necessity to determine the volume of eggs, which requires weighing eggs into distilled water (hydro massage HM). The volume of eggs will be equal to the difference of weight and $H M(V=M-H M)$. The density of fresh eggs is an average $1,085 \mathrm{~g} / \mathrm{cm}^{3}$. As the egg ages, it decreases, and if the value is less than one, the egg floats in fresh water becoming completely unsuitable as food and for incubation. For simplifying, suggest evaluating of freshness of eggs not by density and by hydro-density $(H D)$ that divided by the volume not the weight of the eggs. $(H M): H D=H M / V$, and 
express not $\mathrm{g} \cdot \mathrm{cm}^{-3}$ and $\mathrm{mg} \cdot \mathrm{cm}^{-3}$. Then $D=1.085 \mathrm{~g} \cdot \mathrm{cm}^{-3}$ is equal to $H D=85 \mathrm{mg} \cdot \mathrm{cm}^{-3}$. Hydro-density is the density of eggs into water, the density reduced by $1 \mathrm{~g} \cdot \mathrm{cm}^{-3}$ and multiplied by 1000 (mg instead grams). Hydro-density of fresh chicken eggs $\left(H D_{1}\right)$ with normal thickness shell equals in average to $85 \mathrm{mg} \cdot \mathrm{cm}^{-3}$. In the experiment $H D_{2}$ samples of eggs after 25 days storage it was equal to $35 \mathrm{~g} \cdot \mathrm{cm}^{-3}$, i.e. the loss of the HD amounted to $50 \mathrm{mg} \cdot \mathrm{cm}^{-3}$, that is numerically equal to $5 \%(50 / 10)$ weight loss relative to the volume of eggs or $0.2 \%$ per day. The freshness of eggs is conveniently expressed as the ratio of $H D_{2} / H D_{1}$ in percent. In this example, $(35 / 85) \times 100=41.2 \%$. This ratio had been suggested according to the index of freshness $(I F)$. If absolutely fresh eggs equal $100 \%$, the eggs popup in fresh water $-0 \%$.

However, often the average hydro-density of fresh eggs deviates from $85 \mathrm{~g} \cdot \mathrm{cm}^{-3}$. Therefore, in responsible cases, it is necessary to clarify the initial $H D_{1}$. This can be done by measuring the elastic deformation of eggs $(E D)$ by the developed table (Table 1).

It is established that $E D$ of eggs and its volume in storage is not modified and highly related with its initial density.

Table 1

Elastic deformation of the shell and hydro-density fresh chicken eggs $(n=2500)$

\begin{tabular}{|c|c|c|c|c|c|c|c|}
\hline$E D, \mu \mathrm{m}$ & $H D, \mathrm{mg} \cdot \mathrm{cm}^{-3}$ & $E D, \mu \mathrm{m}$ & $H D, \mathbf{m g} \cdot \mathrm{cm}^{-3}$ & $E D, \mu \mathrm{m}$ & $H D, \mathrm{mg} \cdot \mathrm{cm}^{-3}$ & $E D, \mu \mathrm{m}$ & $H D, \mathrm{mg} \mathrm{cm}^{-3}$ \\
\hline 16 & 93.0 & 21 & 86.0 & 26 & 79.5 & 31 & 74.0 \\
\hline 17 & 91.5 & 22 & 84.5 & 27 & 78.0 & 32 & 73.0 \\
\hline 18 & $\begin{array}{l}90.0 \\
\end{array}$ & 23 & 83.0 & 28 & 77.0 & 33 & 72.0 \\
\hline 19 & 88.5 & 24 & 82.0 & 29 & 76.0 & 34 & 71.0 \\
\hline 20 & 87.0 & 25 & 80.5 & 30 & 75.0 & 35 & 70.0 \\
\hline
\end{tabular}

Hydro-density $86 \mathrm{mg} \cdot \mathrm{cm}^{-3}$ corresponds to $21 \mu \mathrm{m}$ elastic deformations of the shell by normal mineral and vitamin nutrition of laying hens. In rare cases, $E D$ of the samples of fresh eggs is more than $25 \mu \mathrm{m}\left(80.5 \mathrm{mg} \cdot \mathrm{cm}^{-3} \mathrm{HP}\right)$, but by individual eggs oscillations of $E D$ sometimes cover the whole table.

To estimate the freshness index of eggs it is necessary to determine the hydro-density of the evaluation samples $\left(H D_{2}\right)$ and measure the elastic deformation of the shell to find $H D_{1}$ (table). If $H D_{2}=60.0 \mathrm{mg} \cdot \mathrm{cm}^{-3}$, and $H D_{1}-88.5 \mathrm{mg} \cdot \mathrm{cm}^{-3}(U D=19)$, the freshness index of the sample is equal to $67.8 \%(60.0 / 88.5)$. The similar table had been designed for determining the initial hydro-density of quail eggs (Table 2).

Elastic deformation of the shell and hydro-density fresh quail eggs $(n=2500)$

Table 2

\begin{tabular}{|c|c|c|c|c|c|c|c|}
\hline$E D, \mu \mathrm{m}$ & $H D, \mathrm{mg} \cdot \mathrm{cm}^{-3}$ & $E D, \mu \mathrm{m}$ & $H D, \mathrm{mg} \cdot \mathrm{cm}^{-3}$ & $E D, \mu \mathrm{m}$ & $H D, \mathrm{mg} \cdot \mathrm{cm}^{-3}$ & $E D, \mu \mathrm{m}$ & $H D, \mathrm{mg} \mathrm{cm}^{-3}$ \\
\hline 16 & 76.0 & 21 & 72.0 & 26 & 67.5 & 31 & 64.0 \\
\hline 17 & 75.0 & 22 & 71.0 & 27 & 67.0 & 32 & 63.0 \\
\hline 18 & 74.5 & 23 & 70.0 & 28 & 66.5 & 33 & 62.5 \\
\hline 19 & 73.0 & 24 & 69.0 & 29 & 66.0 & 34 & 61.0 \\
\hline 20 & 72.5 & 25 & 68.0 & 30 & 65.0 & 35 & 60.0 \\
\hline
\end{tabular}

The freshness of eggs is also determined by using salt solutions. By using a hydrometer discrete lines of sodium chloride solutions of various concentrations (densities)are prepared, for example: $1.065,1.070,1.075 \mathrm{mg} \cdot \mathrm{cm}^{-3}\left(65,70,75 \mathrm{mg} \cdot \mathrm{cm}^{-3}\right)$. Sinking eggs into solution $\mathrm{HP} 75 \mathrm{mg} \cdot \mathrm{cm}^{-3}$ are sufficiently fresh, but floating in the solution with HP $65 \mathrm{mg} \cdot \mathrm{cm}^{-3}-$ doubtful suitability. The method is related to the complexity of making and maintaining the solution of the desired concentration and, as shown in earlier studies, greatly inferior to a method of double weighing the eggs (in the air and in water). Methods for determining the freshness by air chambers, the mass loss and density are associated with shrinkage of eggs. This assumes that eggs packed in a lumpy strip of papier-mache or other material do not prevent evaporation of moisture through the shell. Hermetic packing of eggs or after they are processed by substances closing the pores of the shell do not work and to judge about the "age" of eggs is possible according to the degree of mobility yolk. In a fresh egg yolk is sedentary. The mobility increases with aging eggs when diluted and decreases dense protein and yolk loses 
density by transition into it water of protein. By liquefied protein, the vibration amplitude of yolk inside the egg increases significantly. Visual assessment of the age of eggs is based on scanning by light: the more mobile yolk, the older is the egg.

At the Saint-Petersburg State Agrarian University an objective method is developed for assessment of mobility of yolk. The measurement principle of this indicator is based on the ability of yolk to reflect light passing through the egg, and the closer yolk to the light source, the higher intensity of the reflected light. The yolk mobility is significantly affected by temperature. This explains the different volume expansion of yolk and albumen by heat. It is established experimentally that the volume expansion of protein by $1{ }^{\circ} \mathrm{C}$ is equal to 0.00019 , yolk -0.00043 , i.e. more than 2.36 times. In this regard, by temperature changes, the density of albumen and yolk changes not equally. Thus, by heated from 8 to $25^{\circ} \mathrm{C}$ the density of albumin decreased from 1.0309 to $1.0275 \mathrm{~g} \cdot \mathrm{cm}^{-3}$, and the density of yolk -1.0316 to $1.0267 \mathrm{~g} \cdot \mathrm{cm}^{-3}$ [9]. In this regard, evaluating freshness of eggs by the mobility of yolk can be done only by equal temperature.

In international practice, freshness of eggs is determined after autopsying by the height of standing outer dense albumin onto a horizontal surface. The index of albumin and Xay units is connected by the high correlation coefficient $(r=0.90 \ldots 0.95)$, so only one of these indicators can be used, but often Xay units are used (easier to weigh the egg than to measure the average diameter of the spreading protein). To measure the index of yolk its height is divided by the average diameter and also expressed in percentage. The higher the index of albumen and yolk, or Xay units, the egg is fresher. Disadvantages of determining freshness of eggs by the index (Xay units) are connected with a necessity to autopsy and its complexity. The advantage is a possibility to determine freshness of eggs regardless of the type of packaging, even of they are completely isolated from the external environment (closing the pores).

\section{Conclusions}

1. The authors consider that the best measure of the "age" of eggs by shrinkage is the index of freshness - ratio (\%) of hydro-density to initial hydro-density of the sample (prior to storage), defined by the authors' table.

2. As an additional indicator of freshness of eggs the index of albumin or Xay units can serve.

\section{References}

1. Фисинин В.И., Гущин В.В., Лукашенко В.С., Агафоничев В.П., Штелле А.Л., Лысенко М.А., Шевяпов А.Н. Пищевая и биологическая ценность яиц и яичных продуктов (Nutritional and biological value of eggs and egg products). Справочник, 2013, 28 p. (In Russian).

2. Sadovoy, V., Omarov, R., Shlykov, S., Shchedrina, T. Assessment compliance of qualitative food characteristics to standard requirements. 15th International Scientific Conference on Engineering for Rural Development, May 25-27, 2016, Jelgava, Latvia, pp. 360-363.

3. Дядичкина Л.Ф., Позднякова Н.С. Хранение инкубационных яиц - необходимая составляющая технологии воспроизводства птицы (Storage of hatching eggs - necessary part of the technology to reproduction birds). Птицеводство, 2015, No 6, pp. 23-27. (In Russian).

4. Романов А.Л., Романова А.И. Птичье яйцо (Bird egg). Птицепромиздат, 1959, 620 p. (In Russian).

5. Царенко П.П., Станишевская О.И. Использование показателя плотности фракций белка инкубационных яиц (ППФ) в селекции мясной птицы (Using indicator of density fractions protein of incubation eggs into selection meat poultry). Известия СПбГАУ, 2009, No 14, pp. 9599. (In Russian).

6. Сафиулова, Ю.Р. Совершенствование методов оценки свежести куриных яиц (Improving methods for determining the freshness chicken eggs). автореф. канд. дисс. 06.02.04, СПб, 2009, 120 p. (In Russian).

7. Царенко П.П., Васильева Л.Т. Методы оценки и повышения качества яиц сельскохозяйственной птицы (Methods for evaluating and improving the quality of poultry eggs), Лань, 2016, 280 p. (In Russian). 
8. Fila, G., A. Bellochi, M. Acutis, and M. Donatelli. IRENE: a software to evaluate model performance. European Journal of Agronomy, 2003, 18, pp 269-372.

9. Deng X., Wang Q., Chen H., Xie H. Eggshell crack detection using a wavelet-based support vector machine. Comput Electron Agric, 2010, 70, pp. 135-143.

10. Cho H.K., Kwon Y. Crack detection in eggs by machine vision. Trans ASAE, 1996, 39 (3), pp. 777-784.

11. Wang J., Jiang R.S. Eggshell crack detection by dynamic frequency analysis. Eur Food Res Technol, 2005, 221, pp. 214-220.

12. Karoui R., Kemps B., Bamelis F., De Ketelaere B., Mertens K., Schoonheydt R., Decuypere E., Baerdemaeker J.D. Development of a rapid method based on front face fluorescence spectroscopy for the monitoring of egg freshness: 1-evolution of thick and thin albumens. Eur Food Res Technol, 2006, 223, pp. 303-312.

13. Karoui R., Kemps B., Bamelis F., De Ketelaere B., Mertens K., Schoonheydt R., Decuypere E., De Baerdemaeker J.D. Development of a rapid method based on front face fluorescence spectroscopy for the monitoring of egg freshness: 2-evolution of yolk. Eur Food Res Technol, 2006, 223, pp. 180-188.

14. Liu Y., Ying Y., Ouyang A., Li Y. Measurement of internal quality in chicken eggs using visible transmittance spectroscopy technology. Food Control, 2007, 18, pp. 18-22.

15. Seregely Z., Farkas J., Tuboly E., Dalmadi I. Investigating the properties of egg white pasteurised by ultra-high hydrostatic pressure and gamma irradiation by evaluating their NIR spectra and chemosensor array sensor signal responses using different methods of qualitative analysis. Chemom Intell Lab Sys, 2006, 82 (1-2), pp. 115-121.

16. Giunchi A., Berardinelli A., Ragni L., Fabbri A., Silaghi F.A. Non-destructive freshness assessment of shell eggs using FT-NIR spectroscopy. J Food Eng, 2008, 89, pp. 142-148.

17. Kemps B., Bamelis F., De Ketelaere B., Mertens K., Tona K., Decuypere E., De Baerdemaeker J.D. Visible transmission spectroscopy for the assessment of egg freshness. J Sci Food Agric, 2006, 86, pp. 1399-1406. 